\title{
Fruit characters and yield of strawberry (Fragaria $x$ ananassa Duch.) as influenced by different concentrations of gibberellic acid
}

\author{
S.H. Ansary ${ }^{1 *}$, N. Mudi ${ }^{2}$, K. Barui ${ }^{3}$, A. Majumdar ${ }^{3}$, N. Gayen ${ }^{2}$ and A. K. Chowdhury ${ }^{2}$ \\ ${ }^{1}$ Nadia Krishi Vigyan Kendra, BCKV, ICAR, Gayeshpur, Nadia, West Bengal, India- 741234 \\ ${ }^{2}$ Hooghly Krishi Vigyan Kendra, BCKV, ICAR, Chinsurah, Hooghly, West Bengal, India- 712102 \\ ${ }^{3}$ Howrah Krishi Vigyan Kendra, BCKV, ICAR, Jagatballavpur, Howrah, West Bengal, India- 711408 \\ Corresponding author e-mail: samsulhaqueansary@gmail.com
}

(Received: 06/02/2021; Revised: 13/05/2021; Accepted: 20/06/2021)

\begin{abstract}
The effect of gibberellic acid concentrations on fruit characters and yield of strawberry was studied on two varieties, namely 'Sweet Charlie' and 'Winter Dawn' during November, 2018 to March, 2019. Foliar application of three different concentration of $\mathrm{GA}_{3}$ viz. $50 \mathrm{ppm}, 75 \mathrm{ppm}$ and $100 \mathrm{ppm}$ were done at 40 days and 60 days after planting. Experimental results showed that $\mathrm{GA}_{3} @ 75 \mathrm{ppm}$ had the best effect to increase yield components and yield of both the varieties. Under $\mathrm{GA}_{3} @ 75 \mathrm{ppm}$, Winter Dawn exhibited higher fruit diameter $(3.38 \mathrm{~cm})$ and fruit length $(4.74 \mathrm{~cm})$ as compared to Sweet Charlie $(3.28 \mathrm{~cm}$ fruit diameter and $4.60 \mathrm{~cm}$ fruit length). Though the fruit weight was slightly higher in Sweet Charlie (18.36g) as against Winter Dawn $(17.90 \mathrm{~g})$ under the best treatment i.e. $75 \mathrm{ppm}$ $\mathrm{GA}_{3}$ the yield recorded was higher in Winter Dawn (573.62g/plant and 24.04t/ha) as against Sweet Charlie (445.43g/plant and $18.73 \mathrm{t} / \mathrm{ha}$ ) due to higher number of fruits (32.44/plant) produced by Winter Dawn as compared to Sweet Charlie (24.94/plant). So, Winter Dawn variety produced $28.35 \%$ higher yield as compared to Sweet Charlie under $\mathrm{GA}_{3} @ 75$ ppm treatment.
\end{abstract}

Keywords: Strawberry, Gibberellic acid, Foliar application, Fruit character, Yield

\section{INTRODUCTION}

Strawberry (Fragaria $X$ ananassa Duch.) is a popular fruit which is best known for its flavour, taste, fresh use and processing purposes. Fruits of strawberry are most attractive, delicious and refreshing having rich source of antioxidant, vitamin $\mathrm{C}$ and phenolic compounds. Fruits are also rich source of minerals and nutrients and having anti cancerous property. In West Bengal its commercial cultivation is mainly concentrated in some pockets of North Bengal. Recently the interest in strawberry production is increasing rapidly due to its high price value and more demand. There is good scope for its cultivation in different parts of West Bengal having congenial climate if right varieties are selected. But farmers are facing many problems for its successful cultivation mainly due to poor growth and low fruiting. Due to lack of standardized production technology and proper technical knowhow, farmers are facing some sorts of problem in commercial production of strawberry. Lack of application of proper nutrients and particularly growth promoting substances is the major cause of poor growth and fruiting in strawberry especially when temperature starts rising. Different reports showed that hormones regulate the plant growth and increase the yield of strawberry (Kumar et al., 2012; Khunte et al., 2014). Foliar application of $\mathrm{GA}_{3}$ has been successfully proved to have increased the yield and quality of different horticultural crops (Sharma and Singh, 2009). Gibberellins promote cell division and elongation (Anonym, 2017). Growth regulating chemicals are becoming important in strawberry for the modification of their vegetative growth, flowering and fruiting affecting total yield and also quality (Vishal et al., 2016; Palei et al., 2016). Therefore, growth regulators at optimum doses and proper growth stages are very essential for increasing growth and production in strawberry. Considering the above views this study was conducted with three different concentration of gibberellic acid $\left(\mathrm{GA}_{3}\right)$ to find out the optimum concentration of gibberellic acid for the improvement of fruit size and yield of strawberry.

\section{MATERIALS AND METHODS}

The experiment was carried out at Instructional Farm of Hooghly Krishi Vigyan Kendra, Chinsurah, Hooghly district of West Bengal during November, 2018 to March, 2019. The experimental site comes under subtropical humid region. The average temperature ranges from $15-20^{\circ} \mathrm{C}$ during December-January and $25-$ $30^{\circ} \mathrm{C}$ during March-April. The soil of the experimental field was clay loam having high water holding capacity with $\mathrm{pH}$ around 6.6. Two varieties of strawberry 
namely 'Sweet Charlie' and 'Winter Dawn' were taken for the study. Three different treatment concentration of gibberellic acid $\left(\mathrm{GA}_{3}\right)$ was taken along with control. The treatments were T-1: Foliar application of $\mathrm{GA}_{3} @$ $50 \mathrm{ppm}$ twice at 40 DAP and 60 DAP, T-2: Foliar application of $\mathrm{GA}_{3} @ 75 \mathrm{ppm}$ twice at 40 DAP and 60 DAP, T-3: Foliar application of $\mathrm{GA}_{3} @ 100$ ppm twice at 40 DAP and 60 DAP and T-4: Control (No use of $\left.\mathrm{GA}_{3}\right),(* D A P=$ Days After Planting $)$.

The experiment was laid out in a Randomized Block Design with five replications. Along with organic manure (Vermicompost @ 3.0 t/ha) a dose of NPK @ 50:80:80 kg/ha was applied as basal to all plots. Foliar spray of top-dressing fertilizer i.e., NPK (19:19:19) @ $5 \mathrm{~g} / \mathrm{L}$ was given at $20 \mathrm{DAP}, 35 \mathrm{DAP}, 50 \mathrm{DAP}$ and 70 DAP to all plots. Micronutrient mixture (Zn, B, Mo, $\mathrm{Cu}) @ 2.0 \mathrm{~g} / \mathrm{L}$ was applied to all plots during flowering. All plots were covered with black/silver plastic mulch. $\mathrm{GA}_{3}$ was applied as per treatment schedule. The planting was done during $1^{\text {st }}$ week of November, 2018 in open field and harvesting was started during $1^{\text {st }}$ week of January, 2019 and continued till last week of March, 2019. The observations recorded were i) Number of fruits per plant ii) Diameter of fruits iii) Length of fruits iv) Average fruit weight and v) Yield. The recorded data were statistically analyzed.

\section{RESULTS AND DISCUSSION \\ Fruit characters}

Fruit characters like fruit diameter and fruit length were significantly varied by different concentrations of gibberellic acid for both the varieties (Fig.1 \& 2). Application of $\mathrm{GA}_{3}$ increased the diameter and length of fruits over control and dose of $75 \mathrm{ppm} \mathrm{GA}_{3}$ resulted highest fruit size followed by $100 \mathrm{ppm} \mathrm{GA}_{3}$. Highest fruit diameter $(3.28 \mathrm{~cm}$ and $3.38 \mathrm{~cm})$ and fruit length $(4.60 \mathrm{~cm}$ and $4.74 \mathrm{~cm})$ were recorded under $75 \mathrm{ppm} \mathrm{GA} 3$ treatment (T-2) in both Sweet charlie and Winter Dawn varieties respectively, whereas without application of growth regulator resulted smaller fruits. Application of $\mathrm{GA}_{3}$ might increase carbohydrate level and dry matter content due to higher photosynthesis rate and increase cell division and elongation which leads to larger fruits. Again $75 \mathrm{ppm} \mathrm{GA}_{3}$ accelerated higher fruit growth and development as compared to $50 \mathrm{ppm}$ and $100 \mathrm{ppm} \mathrm{GA}_{3}$. Beyond $75 \mathrm{ppm}$ concentration $\mathrm{GA}_{3}$ might cause excessive elongation of fleshy receptacles which might reduce fruit size. According to Saima et al. (2014) fruit weight and volume of strawberry are increased by growth regulators. Jamal Uddin et al. (2012) and Kumar et al. (2014) also reported that there were increases in fruit sizes, weight, yield and water-soluble dry matter due to GA treatments. Sarita Paikra (2018) found that fruit length, fruit width, fruit weight, fruit volume, fruit diameter and yield per plant as well as yield were increased considerably in strawberry cv. Sabrina with application of RDF + Gibberellic acid 75 ppm (T3).

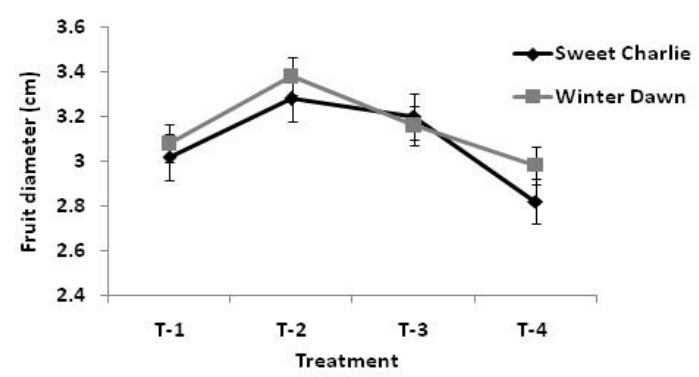

Fig. 1: Effect of gebberellic acid concentration on fruit diameter of strawberry

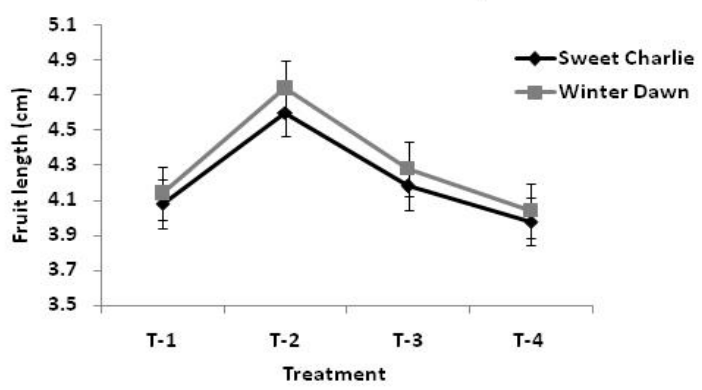

Fig. 2: Effect of gebberellic acid concentration on fruit length of strawberry

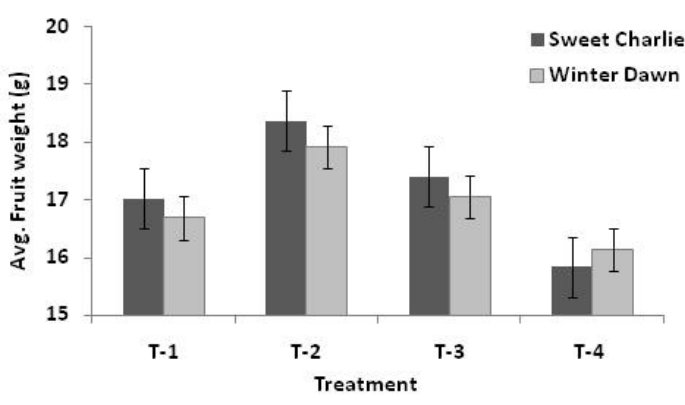

Fig. 3: Effect of gebberellic acid concentration on fruit wieght of strawberry

Yield component and Yield

The yield components and yield were significantly influenced by application of gibberellic acid and the results showed that all concentrations of $\mathrm{GA}_{3}$ increased fruit weight, number of fruits and yield significantly over control in both the varieties of strawberry (Fig.3, $4,5 \& 6)$. Highest average fruit weight $(18.36 \mathrm{~g}$ and $17.90 \mathrm{~g})$ number of fruits per plant (24.94 and 32.44), yield per plant $(445.43 \mathrm{~g}$ and $573.62 \mathrm{~g}$ ) and yield per hectare (18.73t and 24.04t) was recorded under $\mathrm{GA}_{3} 75$ ppm treatment (T-2) in both the varieties Sweet Charlie and Winter Dawn, respectively. The increase in number of fruits might be due to higher fruit set ability by $\mathrm{GA}_{3}$ treatments and higher yield might be due to the increased fruit set per plant, fruit length and fruit diameter as well as fruit weight. Though the average fruit weight is somewhat more in Sweet Charlie, but due to production of higher number of fruits per plant Winter Dawn resulted higher yield as compared to Sweet Charlie. Again, reduction of fruit weight beyond $75 \mathrm{ppm}$ concentration of $\mathrm{GA}_{3}$ might be due to excessive elongation of fleshy receptacles in the fruits. Similar results were found by Thakur et al. (2015) that the $\mathrm{GA}_{3}$ 
75 ppm gave best result in terms of plant growth, yield and fruit quality as compared to other treatments. Yadav et al. (2017) showed that foliar spray of $\mathrm{GA}_{3} 75$ ppm after 45 days of transplanting was found superior over all other treatments with respect to various parameters to enhance strawberry yield. Whereas some Researchers found best effect on strawberry by application of $\mathrm{GA}_{3} 100$ ppm (Tripathi and Shukla, 2010; Singh and Singh, 2009; Kumar and Tripathi, 2009).
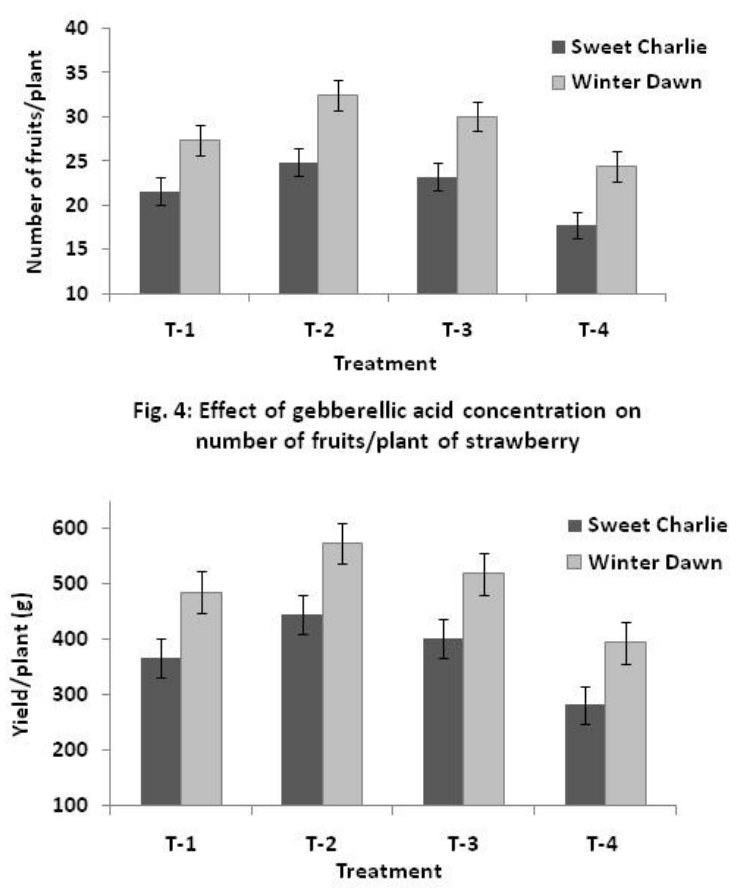

Fig. 5: Effect of gebberellic acid concentration on yield/plant of strawberry

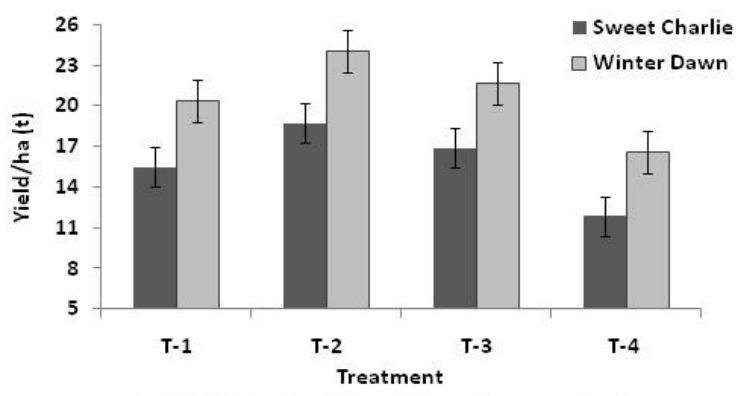

Fig. 6: Effect of gebberellic acid concentration on yield/ha of strawberry

\section{CONCLUSION}

Based on the experimental results, it can be concluded that application of gibberellic acid can increase bearing capacity, fruit size and yield in strawberry. Application of $\mathrm{GA}_{3} @ 75$ ppm twice at 40 DAP and 60 DAP had the best effect to increase fruit-set, number of fruits per plant, fruit size and yield. Again, Winter Dawn variety produced $28.35 \%$ higher yield as compared to Sweet Charlie under $\mathrm{GA}_{3}$ @ 75 ppm treatment. Therefore, cultivation of strawberry with application of $75 \mathrm{ppm}$ $\mathrm{GA}_{3}$ can bring ample scope for increasing fruit size and yield in strawberry to fetch more profit for the farmers.
Again, the variety Winter Dawn may be selected to achieve higher yield for getting better remuneration.

\section{ACKNOWLEDGEMENT}

We are very thankful to Project Director, Agriculture Technology Management Agency (ATMA), Hooghly for providing necessary financial assistance for conducting the research.

\section{REFERENCES}

Anonymous2017.http://tr.wikipedia.org/wiki/Giberellin (Access date: 21.04.2017).

Jamaluddin, A.F.M., Hossan, M.J., Islam, M.S., Ahsan, M.K. and Mehraj, H. 2012. Strawberry growth and yield responses to gibberellic acid concentrations. J. Expt. Biosci. 3(2): 51-56.

Khunte, S. D., Kumar, A., Kumar, V., Singh, S. and Saravanan, S. 2014. Effect of plant growth regulators and organic manure on physicochemical properties of strawberry (Fragaria $\mathrm{x}$ ananassa Duch.) cv. Chandler. Int. J. of Sci. Res. and Edu., 2(7): 158-165.

Kumar, R. and Tripathi, V.K. 2009. Influence of NAA, GA3 and boric acid on growth, yield and quality of strawberry cv. Chandler. Prog. Horti., 41(1): 113- 115 .

Kumar, R., Bakshi, P., Srivastava, J.N. and Sravanan, S. 2012. Influence of plant growth regulators on growth, yield and quality of strawberry (Fragaria $\mathrm{x}$ ananassa Duch.) cv. Sweet Charlie. The Asian J. of Hort., 7(1): 40-43.

Kumar, R., Saravanan, S., Jasrotia, A., Bakshi, P., Shah, R., Raina, V. 2014. Influence of gibberellic acid and blossom removal on flowering and yield of strawberry (Fragaria $\mathrm{x}$ ananassa Duch.) cv. Belrubi. Int. J. of Agri. Sci., 10(1): 272-275.

Palei, S., Das, A.K., Sahoo, A.K., Dash, A.K. and Swain, S. 2016. Influence of plant growth regulators on strawberry Fragaria $\mathrm{x}$ ananassa $\mathrm{Cv}$. Chandler) Under Odisha conditions. Int. J. of Recent Sci. Res., 7(4): 9945-9948.

Saima, Z., Sharma, A., Umar, I. and Wali, V.K. 2014. Effect of plant bio-regulators on vegetative growth, yield and quality of strawberry cv. Chandler. African J. of Agri. Res., 9(22):16941699.

Sarita Paikra 2018. Influence of NAA and GA3 on growth, flowering, yield and quality of Strawberry (Fragaria $\mathrm{x}$ ananassa Duch.) cv. Sabrina under net tunnel. M.Sc. (Hort.) Thesis, Dept. of Fruit Science, College of Agriculture, Indira Gandhi Krishi Viswavidyalaya, Raipur, pp 107.

Sharma, R.R., and Singh, R. 2009. Gibberellic acid influences the production of malformed and button berries, and fruit yield and quality in strawberry (Fragaria xananassa Duch.). Scientia Hort. 119(4): 430-433. 
Singh, A. and Singh, J.N. 2009. Effect of bio-regulators on growth, yield and nutrient status of strawberry cv. Sweet Charlie. Indian J. Horti., 66(2): 220224.

Thakur, S., Mehta, K. and Sekhar, R.S. 2015. Effect of GA3 and plant growth promoting rhizobacteria on growth, yield and fruit quality of strawberry (Fragaria $\times$ ananassa Duch.) cv. Chandler. Int. J. Advanced Res., 3(11): 312 -317.

Tripathi, V. K. and Shukla, P.K. 2010. Influence of plant bio-regulators on yield and fruit characters of Strawberry cv. Chandler. Prog. Horti., 42(2): 186-188.
Vishal, V. C., Thippesha, D., Chethana, K., Maheshgowda, B. M., Veeresha, B. G. and Basavraj, A. K. 2016. Effect of Various Growth Regulators on Vegetative parameters of strawberry (Fragaria $\mathrm{x}$ ananassa Duch.) Cv. Sujatha. Res. J. Chemical and Env. Sci., 4(4): 6871.

Yadav, I., Singh, J., Meena, B., Singh, P., Meena, S., Neware, et al. 2017. The effect of foliar application of growth regulators and micronutrients on production of strawberry (Fragaria x ananassa Duch.) cv. Winter Dawn under open field condition. Chem. Sci. Rev. Lett., 6(21): 589-594.

Citation: Ansary, S.H., Mudi, N., Barui, K., Majumdar, A., Gayen, N. and Chowdhury, A. K. 2021. Fruit characters and yield of strawberry (Fragaria $x$ ananassa Duch.) as influenced by different concentrations of gibberellic acid. International Journal of Agricultural and Applied Sciences, 2(1):126-129. https://doi.org/10.52804/ijaas2021.2114

Copyright: () Ansary et.al. 2021. Creative Commons Attribution 4.0 International License. IJAAS allows unrestricted use, reproduction, and distribution of this article in any medium by providing adequate credit to the author(s) and the source of publication. 